former communication ho suggests tha following classification by atages: I. Simplo inflammntory rhinitis, a. Irritnbility of crectilo tissuo. . $\beta$. Permanent dilatation of ereetila tissuc. II. Hypertrophio rhinltis. a, Dilatntion. with hypertroplyy. $\beta$. Completo hypertroplyy. III, Atrophie rhinitis, a. Conmencing ntropliy. $\beta$, Completo atrophy.

In tho latter artiele, n microscopical scetion througlı tho inferior turbinated bone of a man dend of Bright's disease, tho result of long-standing mitral insufticlency, is presented as tha probabla pieturo of tho histologienl ehninges in acuta eoryza. Another section illustrates dilatation with hypertrophy in clironie nasal inflammation. Dr. Mackenzio recognizes four modes by which tho creetile sprees beeomo obliternted in nusal inflammation. 1. By tho contraction of newly formed intercellular fibrous bands, 2. By obliteration of their lumen by mases of lymphoid eells. 3. By the formation of thrombi. t. By tho process of septa formation. Tha nuthor refers to tho interdepen. dence of elironic nasnl and chronle antral Inflanmutlon, and the rarity of sccondary involvement of the antrum.

Tho samo writer (New York Medical Journal, September 12, 1885) refuses to "nscribo all discases to tho peripatetic cxeursions of a vagrant micrococeus;" nor does loe censider dust tho prominent factor that it is sometimes nlleged to bo in tho localization of hifammatory disenso in tho nasopharynx. Varlablo climatio conditions, nul defeetivo nssimilation from whatever cause, whether hereditary or acquired talut, or indiscrotlons or oxcesses of any $k$ ind, seem tho principal oxciting and predispesing causes of simple inflammatlons of the Ilper respiratory truet.

\title{
Thenthent of Chronio Conyza:
}

At tho mecting of tho Amerlem Laryugological Associntlon, June, 1885, promlncuco was given in debnto to tho uso of mild measures, such as persistont dihatation of tho obstructed nasnl passages by means of compressed tubes of laminnia, with eflicicnt cleansiug by means of slightly aromatlzed alkalina sprays; supplemonted by great attontion townd keeping tho varlous emunctories in marked netivity, and such general hygienic nnd dietetic regulations and eonstitutionnl mediention as tho lndividuality of tho ense inight demand. - Med. News, July 4, 1885 .

\section{OzRENA,}

Dr. E. J, Moune (Soc. franc. de Laryngol, April, 18855; Annales des mal., (le toreille, etc., September, 1885) does not admit the ineurabillty of ozwna. Ile proposes tho uso of tho nasnl douche with solutions of sodium bicarbonate, chlorntc, or chloride, to soften and detach tho crusts, followed by antiseptic irrigations, and insuflntion of astringent powders; with constitutional medication by cod-liver oll or potassium iodlde, tho use of tho Pyrennean thermal waters, and sojourn at tho senshore.

Dr. S. Solis-Confe, in a communication to tho American Iaryngologieal Association (Annales des Mfaladies de Poreille, du Jarynx, etc., Sept, 1885), considers solution of hydrogen diexido (10 vol, diluted, if necessary, with one or two parts of distilled nnd arematized water) the best detergent and disinfec- 
tant in fetid coryza; and aseribes to it $\boldsymbol{n}$ certnin power in stimulating the reproduction of healthy cpithelium. Fithyl iodide, hy inhalation, was also favornhly mentioned.

\section{Tanjonina tuk Naneg; Hryommatis.}

For guiding tho tampon, tho compiler has for more than two yenrs used simply a slender, flexilhlo eopper wirc, lended at ono end like "I piu. The other extremity is turned up, at will, into $n$ loop to which is attashed the threal. The contrivanco is passed in throngh the nostril and ont througl the mouth, and then ent from tho thread, which now presents a free end at nose and month. Then tho tampon is attached nel pulled backword his the usunt manner. Quito recently ho has leurned that, for tho same purpose, the Inpance emplny a spill made of a roll of uarrow paper. A piece of bell wire can he utilized il an emergency. The copper wire, ns ubove, nuswers aluirahly as a cotton-holder. It bends readily at nuy movement of tho patient, and is thus rendered harmless. Simall seetions of wire ean be uounted on holders nud handles.

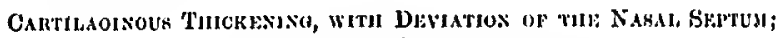
Successful Ojinktios,

Du. Brwenuy Ronisson (Aled. Record, N. Y., 1885, ulso private communl. cution) reports a case of thickening of the cartilaginous septum with doviation, completcly oecluding tho right nusal pasuge, but allowing a littlo air to pass through tho left side on great cxertion. Gradnully jnereasing diflieulty in musal respiration, with mosmia, immillty to sleep or cat with comfort, and secoudary bronclitic astluma, hasl followed $n$ blow on the noso four yeurs pre. vlously. For fivo mouths tho paticut lad heen unablo to closo her mouth day or night. Tho thickened tiswiles wero removed from tho right side hy means of WV clr's gouge foreeps, and, Inter on, soft metallic lougies wero pissed dhily for twelvo days. At ono timc, exuhcrant granulations wero ropressed by clilorido of iron. At another, npplieations of monochloracetic nuid were mado ln hotl । usal passages. Complete relicf from ull anmoying symptons was afforded.

\section{HYoTkHL. S. Skikinot.}

Cinancot (reported in Brit. J/Cd. Journ., Jnly 25, 1885) whowed at his eliniv a girl aged sixteen, of a well-marked nenrotis tendeney, with hemianesthesin ou the left side, und liysterogenic zones in the right hrenst and in the len orariạı region, who is subject to nttneks of paroxysmal sucezing. The fits aro preceded by a feeling of globus ligstericns, and consist in nerrons congh, lunghter, and sprsuodic sncezing, sometimes nlso yuwning. Opisthotonos frequently oceurs. Tho patient sneczes from thirty to forty times a minute. Thero is no hypensecretion from the mincons membrume of the nose.

\section{Lax Fuven.}

This subject, of pereunlal lnterest, lins this year boen more thun usually prominent in professlonal cirelex. Tho oluservations of Daly, Roc, Allen, 